\title{
Granice dopuszczalności stosowania wykładni pozajęzykowej w prawie podatkowym na przykładzie opodatkowania zbiorników wodnych retencyjnych podatkiem od nieruchomości
}

Problematyka dopuszczalności stosowania wykładni pozajęzykowej, chociaż istotna dla całego systemu prawa, nabiera szczególnego znaczenia w odniesieniu do ustalania sensu przepisów prawnych, których normy nakładają na obywateli obowiązki o charakterze fiskalnym na rzecz Skarbu Państwa lub jednostek samorządu terytorialnego. Podmiot zobowiązany do świadczenia pieniężnego może domagać się od ustawodawcy na etapie tworzenia jak największej przejrzystości przepisów, tak aby jego obowiązek nie musiał być „domniemywany”" na etapie stosowania prawa. Inaczej bowiem niż np. w prawie cywilnym, w ramach którego równorzędne podmioty współkształtują treść stosunku prawnego na podstawie norm prawnych, podatnik ,zdominowany” władztwem podatkowym wierzyciela podatkowego nie ma żadnego wpływu na treść więzi prawnej. Fakt ten oznacza oczywiście, iż z uwagi na brak równorzędności podmiotów niewskazane jest pozostawianie zbyt dużej swobody interpretacyjnej. Z drugiej strony nie można zapominać o skrajnie oczywistej kwestii, iż żaden ustawodawca nie jest w stanie na poziomie semantycznym, we wszystkich przepisach, zawrzeć całego zamierzonego sensu powoływanych do życia przepisów, a w wielu przypadkach byłoby to nawet niewskazane. Wręcz przeciwnie, z uwagi na coraz większą złożoność stosunków społecznych czy gospodarczych ujmowanie sensu przepisu prawnego w ramach jednoznacznych sformułowań językowych staje się zadaniem coraz bardziej karkołomnym. Skutkuje to oczywiście koniecznością odwoływania się do znaczeń pozajęzykowych w procesie stosowania prawa. Tym bardziej zatem

* Dr Marek Kopyściański - Katedra Prawa Finansowego, Wydział Prawa, Administracji i Ekonomii, Uniwersytet Wrocławski.

${ }^{1}$ Użycie zwrotu „domniemywany” wynika z potrzeby odzwierciedlenia powszechnego odczucia przeciętnego podatnika, a nie z rażącego lekceważenia pozajęzykowej wykładni, która oczywiście w procesie ustalania sensu przepisu prawnego ma takie samo znaczenie, jak wykładnia językowa, choć nie zawsze w konkretnych sytuacjach łatwo jest właściwie zastosować poszczególne metody. 
istotne staje się poszukiwanie granic dopuszczalności stosowania wykładni pozajęzykowej, skoro ustalenie sensu przepisu prawnego niezwykle często wymaga sięgnięcia poza sens językowy.

Bezspornie za celowe należałoby uznać dążenie do używania w przepisach podatkowo-prawnych zwrotów językowych, których znaczenie na tyle nie budziłoby wątpliwości co do ich sensu, że stosowanie wykładni pozajęzykowej miałoby ograniczony zakres ${ }^{2}$. Za takim podejściem przemawia charakter prawa podatkowego, a także konieczność wynikająca z konstytucyjnej zasady demokratycznego państwa prawa, przestrzegania szeroko rozumianej podatkowej zasady pewności opodatkowania. Podatnik, podporząakowując swoje zachowanie dyspozycji normy podatkowo-prawnej, nie może być postawiony w sytuacji niepewności, czy jego zachowanie będzie, czy nie będzie skutkowało poniesieniem w przyszłości ciężaru podatkowego, albo w jakiej wysokości ten ciężar będzie ostatecznie ustalony lub określony przez organ podatkowy. Z drugiej strony zasada pewności opodatkowania nie może też być rozumiana tak, że w przypadku niebudzących wątpliwości na poziomie językowym przepisów prawnych, lecz stawiających $\mathrm{w}$ związku z tym podatnika w niekorzystnej z jego punktu widzenia sytuacji, podatnik odwołuje się do wykładni pozajęzykowej. Zasada pewności opodatkowania i wynikająca $\mathrm{z}$ niej w pewnym stopniu konieczność ostrożnego stosowania wykładni pozajęzykowej nie zależy bowiem od tego, czy przeprowadzenie wykładni językowej prowadzi do korzystnych czy niekorzystnych konsekwencji dla podatnika ${ }^{3}$.

Jednym z przykładów trudności związanych z ustalaniem sensu przepisu prawnego i wyznaczaniem granic stosowania wykładni pozajęzykowej jest problem opodatkowania zbiorników wodnych retencyjnych. Z uwagi na używanie zwrotu „zbiorniki wodne retencyjne”, który z jednej strony ma swoje znaczenie słownikowe, ale $\mathrm{z}$ drugiej występuje w języku technicznym (geologiczno-hydrologicznym), można mieć pewne wątpliwości co do faktycznego znaczenia tego zwrotu ${ }^{4}$. Podjęcie próby rozstrzygnięcia tych wątpliwości wymaga prawidłowego zastosowania wykładni językowej i ewentualnie pozajęzykowej.

Wspólną cechą reguł wykładni językowej jest odwoływanie się do językowego kontekstu normy, a więc języka, w którym sformułowany jest przepis prawny, jego różnych odmian (np. języka potocznego, prawnego czy specjalnego), do właściwych dla danego języka reguł znaczeniowych (semantycznych), reguł składni (syntaktycznych), a wreszcie do reguł użycia wyrażeń danego języka (pragmatycznych). Ponadto, należy pamiętać, iż istota wykładni językowej sprowadza się także do ustalenia znaczeń przypisywanych poszczególnym terminom

2 „Celowe” nie oznacza oczywiście możliwe, ani tym bardziej wskazane w każdym przypadku.

3 Szerzej na ten temat zob. R. Mastalski, Stosowanie prawa podatkowego, Warszawa 2008, passim; B. Brzeziński, Szkice z wyktadni prawa podatkowego, Gdańsk 2002, passim.

${ }^{4}$ Problem ten był przedmiotem rozstrzygnięcia Naczelnego Sądu Administracyjnego, zob. wyrok NSA z dnia 12 lutego 2010 r., sygn. akt II FSK 521/09. 
lub odróżniania znaczeń różnych terminów. Posługując się wykładnią językową, należy odróżnić język prawny, w którym sformułowane są teksty prawne, a który stanowi formę przejściową między językami naturalnymi i sztucznymi, od języków prawniczych - języka nauki prawa, języka praktyki prawniczej i wreszcie potocznego języka prawniczego. Niewątpliwie początkiem wykładni jest zawsze język, za pomocą którego sformułowano teksty prawne ${ }^{5}$. Tym samym użyty przez ustawodawcę zwrot „zajęty na...” należy zestawić z językiem prawnym, tj. odwołać się do rozumienia tego zwrotu przez ustawodawcę w kontekstach innych norm. I tak ilekroć ustawodawca używa np. zwrotu „zajęty na prowadzenie działalności gospodarczej", to w języku prawnym oznacza to zajęcie dokonane przez podatnika, którego głównym bądź co najmniej przeważającym celem było wykorzystywanie do prowadzonej działalności gospodarczej (nawet jeśli ostatecznie ten cel nie został w pełni zrealizowany). Aby mówić o jakimkolwiek zajęciu, musi być ono dokonane przez kogoś, a zatem ustawa wiąże określony skutek podatkowy $\mathrm{z}$ zajęciem przez kogoś gruntu na realizację określonego celu. Nie można uwzględniać jedynie fizykalnego sensu zwrotu „zajęty na” z jednoczesnym odrzuceniem możliwości zajęcia czegoś w sensie prawnym, podczas gdy zwrot „zajęty na” występuje w innym kontekście znaczeniowym w języku prawnym, w obszarze prawa podatkowego. Można dla przykładu zwrócić uwagę na następujące przepisy prawa podatkowego, w których ustawodawca używa zwrotu ,zajęty na”:

- art. 2 ust. 2 ustawy o podatkach i opłatach lokalnych ${ }^{6}$ - „opodatkowaniu podatkiem od nieruchomości nie podlegają użytki rolne, grunty zadrzewione i zakrzewione na użytkach rolnych lub lasy, z wyjątkiem zajętych na prowadzenie działalności gospodarczej";

- art. 2 ust. 3 pkt 3 ustawy o podatkach i opłatach lokalnych - ,opodatkowaniu podatkiem od nieruchomości nie podlegają również: nieruchomości lub ich części zajęte na potrzeby organów jednostek samorządu terytorialnego, w tym urzędów gmin, starostw powiatowych i urzędów marszałkowskich";

- art. 5 ust. 1 pkt 1c ustawy o podatkach i opłatach lokalnych - ,pozostałych, w tym zajętych na prowadzenie odpłatnej statutowej działalności pożytku publicznego";

- art. 1 ust. 1 ustawy o podatku leśnym ${ }^{7}$-, ,opodatkowaniu podatkiem leśnym podlegają określone w ustawie lasy, z wyjątkiem lasów zajętych na wykonywanie innej działalności gospodarczej niż działalność leśna";

- art. 5 ust. 4 ustawy o podatku leśnym - „Jeżeli w trakcie roku podatkowego las został zajęty na wykonywanie działalności gospodarczej innej niż działalność leśna lub po zaprzestaniu wykonywania tej działalności przywrócono działalność leśną, albo z innych powodów jego powierzchnia uległa zmniejszeniu lub zwięk-

${ }^{5}$ Zob. R. Mastalski, Stosowanie..., s. 77 i n.

${ }^{6}$ Ustawa z dnia 12 stycznia 1991 r. o podatkach i opłatach lokalnych, t.j. z 2010 r. Dz. U. $\mathrm{Nr} 95$, poz. 613 ze zm.

${ }^{7}$ Ustawa z dnia 20 października 2002 r. o podatku leśnym, Dz. U. Nr 200, poz. 1682 ze zm. 
szeniu - kwota należnego podatku leśnego ulega obniżeniu lub podwyższeniu, poczynając od pierwszego dnia miesiąca następującego po miesiącu, w którym nastąpiła ta zmiana";

- art. 7 ust. 2 pkt 2 ustawy o podatku leśnym - „od podatku leśnego zwalnia się również publiczne i niepubliczne jednostki organizacyjne objęte systemem oświaty oraz prowadzące je organy, w zakresie lasów zajętych na działalność oświatową";

- art. 1 ustawy o podatku rolnym ${ }^{8}$ - „opodatkowaniu podatkiem rolnym podlegają grunty sklasyfikowane w ewidencji gruntów i budynków jako użytki rolne lub jako grunty zadrzewione i zakrzewione na użytkach rolnych, z wyjątkiem gruntów zajętych na prowadzenie działalności gospodarczej innej niż działalność rolnicza";

- art. 6a ust. 4 ustawy o podatku rolnym - ,jeżeli w ciągu roku podatkowego grunty gospodarstwa rolnego zostały zajęte na prowadzenie innej działalności gospodarczej niż działalność rolnicza lub po zaprzestaniu prowadzenia tej działalności przywrócono na tych gruntach działalność rolniczą albo z innych powodów ich powierzchnia uległa zmniejszeniu lub zwiększeniu, kwota należnego podatku rolnego ulega obniżeniu lub podwyższeniu, poczynając od pierwszego dnia miesiąca następującego po miesiącu, w którym nastąpiła ta zmiana".

Organ stosujący prawo podatkowe, w procesie wykładni jest związany znaczeniem nadawanym poszczególnym zwrotom w języku prawnym, a zatem dokonując wykładni zwrotu ,zajętych na zbiorniki wodne retencyjne”, zobligowany jest nie tylko do ustalenia znaczenia zwrotu ,zbiornik wodny retencyjny”, ale także w ramach języka prawnego zwrotu „zajęty na”. Sens tego zwrotu z uwagi na znaczenia nadawane mu w kontekstach innych norm wskazuje niewątpliwie na konieczność zajęcia przez podatnika zbiornika wodnego retencyjnego, przy czym głównym (lub co najmniej przeważającym) celem takiego zajęcia musi być wykorzystywanie zbiornika do celów retencji, a nie do prowadzonej działalności gospodarczej polegającej np. na poborze, uzdatnianiu czy dostarczaniu wody. W związku z użyciem zwrotu ,zajęty na" konieczne jest wykorzystywanie zbiornika na potrzeby retencji nie przy okazji prowadzonej działalności gospodarczej, lecz ewentualne prowadzenie działalności gospodarczej w związku z realizowaniem funkcji podstawowej zbiornika wodnego retencyjnego.

Niewątpliwie prawodawca poprzez słowa określa, co zamierza osiągnąć, a wykładnia językowa zakreśla granice interpretacji prawa w ramach możliwego sensu słów zawartych w tekście prawnym. Wykładnia językowa prawa podatkowego powinna ponadto, oprócz ogólnych reguł dotyczących wykładni, kierować się także jego specyfiką. Stopień związania słowami ustawy podatkowej podmiotu dokonującego wykładni jest bez wątpienia znacznie większy aniżeli w przypadku

${ }^{8}$ Ustawa z dnia 15 listopada 1984 r. o podatku rolnym, t.j. Dz. U. z 2006 r. Nr 136, poz. 969 ze zm. 
prawa cywilnego, które zakreśla jedynie pewne ramy regulacji prawnej (z zasady nie zawsze wyraźnie zarysowane), pozostawiając jej dopełnienie praktyce stosowania prawa. Możliwość dopełnienia materii ustawowej w prawie podatkowym powinna być natomiast ograniczona.

Nakładanie podatków należy do tak zwanej wyłączności ustawowej. Zgodnie $\mathrm{z}$ art. 217 Konstytucji RP ${ }^{9}$ nakładanie podatków, innych danin publicznych, określanie podmiotów, przedmiotów opodatkowania i stawek podatkowych, a także zasad przyznawania ulg i umorzeń oraz kategorii podmiotów zwolnionych od podatków następuje w drodze ustawy. Powyższa norma konstytucyjna nie oznacza tylko obowiązku uregulowania tych kwestii w ustawie. Zgodnie bowiem z zasadą określoności, powyższe elementy powinny być $\mathrm{w}$ akcie rangi ustawowej w sposób bardzo precyzyjny, przejrzysty i jasny uregulowane ${ }^{10}$. $Z$ zasady demokratycznego państwa prawnego wynika, że każda regulacja prawna ingerująca w prawa i wolności obywatelskie musi spełniać wymóg dostatecznej określoności. Należy przez to rozumieć precyzyjne wyznaczenie dopuszczalnego zakresu ingerencji. Adresat normy prawnej musi bowiem wiedzieć, w jaki sposób ma się zachować ${ }^{11}$. Nakaz określoności jest szczególnie istotny w prawie daninowym ${ }^{12}$. Analizując pod tym kątem regulacje prawne, dotyczące np. przedmiotu opodatkowania podatkiem od nieruchomości, należy mieć na względzie zasadę określoności przy nakładaniu daniny publicznoprawnej (art. $2 \mathrm{w}$ związku z art. 217 Konstytucji RP). Zwłaszcza przy mechanizmie samoobliczania podatku, podatnik nie powinien mieć żadnych wątpliwości w zakresie tego, które czynności są przedmiotem podatku od nieruchomości.

Mając na względzie dotychczasowe rozważania, zasadnym wydaje się stwierdzenie, że przepisów art. 2 ust. 3 pkt 2 oraz art. 5 ust. 1 pkt 1 lit. a) i b) ustawy o podatkach i opłatach lokalnych nie można interpretować w taki sposób, że treść pojęcia zbiornik wodny retencyjny powinna być uzupełniona poprzez znaczenia techniczne, specjalistyczne. Na poziomie analizy słownikowej znaczenie pojęcia „zbiornik wodny retencyjny” nie budzi żadnych wątpliwości: „sztuczne jezioro utworzone przez spiętrzenie wód rzeki, potoku za pomocą zapory, wykorzystywane do celów żeglugowych, energetycznych, przeciwpowodziowych, melioracyjnych, rekreacyjnych"13. Na tle takiego brzmienia przepisu, tj. „zajęte na zbiornik wodny retencyjny”, traktowanie jako zbiornika wodnego

${ }^{9}$ Konstytucja RP z dnia 2 kwietnia 1997 r., Dz. U. Nr 78, poz. 483.

${ }^{10}$ Zob. wyrok NSA z dnia 8 kwietnia 2011 r. (I FSK 659/10).

${ }_{11}$ Takie stanowisko wyraził też Trybunał Konstytucyjny w wyroku z dnia 19 czerwca 1992 r., U 6/92, OTK 1992, nr 1, poz. 13. Podobnie w wyroku Trybunału Konstytucyjnego z 10 listopada 1998 r., K 39/97, OTK 1998, nr 6, poz. 99.

12 Zob. wyrok Trybunału Konstytucyjnego z 29 marca 1994 r., K 13/93, OTK 1994, nr 1, poz. 6; z glosą aprobującą R. Mastalski, „Państwo i Prawo” 1994, nr 7-8, s. 136.

${ }_{13}$ Por. definicję w Uniwersalnym słowniku języka polskiego, red. S. Dubisz, t. 4, Warszawa 2003, s. 932. 
retencyjnego np. naturalnych terenów wodonośnych nie da się uzasadnić żadnymi regułami wykładni językowej. Skoro zaś wyniki wykładni gramatycznej są jednoznaczne, za niedopuszczalne należy uznać sięganie do pozostałych rodzajów wykładni ${ }^{14}$. Przemawia za tym ochrona podatnika, tak aby mógł on układać swoje sprawy w zaufaniu do tego, że nałożone na niego przez ustawodawcę ciężary i świadczenia publiczne nie zostaną ukształtowane na jego niekorzyść na podstawie funkcjonalnych czy celowościowych dyrektyw interpretacji prawa. W świetle zasady zaufania obywatela do państwa i stanowionego przez nie prawa, będącej implikacją klauzuli demokratycznego państwa prawnego (art. 2 Konstytucji RP), oraz zasady, zgodnie z którą obowiązek ponoszenia ciężarów i świadczeń publicznych jest ograniczony nakazem absolutnej wyłączności ustawy (art. $84 \mathrm{i}$ art. 217 Konstytucji RP), za niedopuszczalne należy uznać wymaganie od podatnika ponoszenia ciężarów i świadczeń publicznych, które nie wynikają wprost z wypowiedzi ustawodawcy, lecz zostały ukształtowane przez organy stosujące prawo na skutek metod wykładni pozajęzykowej. Sens przepisów prawnych określających ciężary lub świadczenia publiczne nie powinien być w praktyce stosowania prawa podatkowego ustalany w sposób rozszerzający przy wykorzystaniu pozajęzykowych metod wykładni prawa. Użycie pozajęzykowych metod wykładni jest niedopuszczalne zawsze wówczas, gdyby w wyniku ich zastosowania miało dojść do odstąpienia od jednoznacznego brzmienia przepisu prawa. Natomiast dopiero brak jasnej wypowiedzi ustawodawcy upoważnia do przeprowadzenia wykładni pozajęzykowej ${ }^{15}$.

Zgodnie z przytoczoną już definicją słownikową ,zbiornikiem wodnym retencyjnym" jest sztuczne jezioro utworzone przez spiętrzenie wód rzeki, z potoku za pomocą zapory, wykorzystywane do celów energetycznych, żeglugowych, przeciwpowodziowych, melioracyjnych, rekreacyjnych. Zbiornikiem retencyjnym jest zatem zbiornik wodny utworzony przez wybudowanie zapory przegradzającej dolinę rzeki, służący do gromadzenia wody dla celów racjonalnej gospodarki (przyjmowania nadmiaru wód powodziowych, do zasilania rzeki i nawadniania terenów rolnych w czasie suszy) wykorzystywany także do celów energetycznych. Jego głównym celem jest wyrównanie odpływu rzecznego i zgromadzenie wody w okresach jej nadmiaru (retencja), w celu wykorzystania jej w okresie niedoboru. Tym samym w rozumieniu przepisów ustawy o podatkach i opłatach lokalnych zbiornikiem wodnym retencyjnym jest ,zbiornik zbudowany przede wszystkim po to, aby prowadzić racjonalną gospodarkę wodną" na danym terenie, przez którą należy rozumieć gromadzenie wody w czasie jej nadmiaru

${ }^{14}$ W orzecznictwie Naczelnego Sądu Administracyjnego w zasadzie przyjęty jest pogląd, iż możliwość stosowania wykładni pozajęzykowej ma charakter wyjątkowy. Zob. dla przykładu uchwałę NSA z dnia 22 czerwca 2011 r. (I GPS 1/11, ze zdaniem odrębnym).

${ }^{15}$ Odrębną kwestią jest natomiast trudność w ustaleniu w przypadku poszczególnych przepisów prawa podatkowego, czy znaczenie leksykalne w kontekście tekstu prawnego budzi, czy nie budzi wątpliwości. W gruncie rzeczy w wielu przypadkach jest to niezwykle złożony proces. 
i wykorzystywanie jej w okresach niedoboru ${ }^{16}$. W świetle takiego brzmienia przepisu, a także mając na uwadze dotychczasowe ustalenia, wydaje się więc zupełnie niezasadne, w procesie ustalania sensu przepisu prawnego, sięganie do znaczeń wynikających z analizy technicznej, a zatem sięganie bez uzasadnienia do języka technicznego. Dodatkowo można też przyjąć założenie, że ustawodawca świadomie nie zdefiniował w ramach przepisu definicyjnego pojęcia ,zbiornik wodny retencyjny", uznając je właśnie za pojęcie dostatecznie jasno zdefiniowane w języku prawnym. Skoro zamiarem prawodawcy jest niewątpliwie osiągnięcie określonych celów, wynikających z założeń polityki legislacyjnej, a w tym przypadku również polityki podatkowej, tekst prawny musi te cele odzwierciedlać, co jednak nie oznacza, iż może być on formułowany jedynie w języku, jakim posługuje się adresat normy prawnej.

W konkluzji należy stwierdzić, iż oczywiście wykładnia językowa i pozajęzykowa nie mają charakteru wykładni konkurencyjnych. Żadna z nich nie jest mniej lub bardziej istotna w procesie ustalania sensu przepisów prawa podatkowego. Nie ma jednak wątpliwości, iż prawidłowe korzystanie z poszczególnych metod wykładni nie może sprowadzać się do lekceważenia bezspornych znaczeń językowych (inną kwestią jest spór co do ewentualnej bezsporności znaczeń poszczególnych przepisów). Mogłoby to bowiem oznaczać tworzenie zbyt dużej, niedopuszczalnej dowolności w ustalaniu sensu przepisu prawnego. Granica dopuszczalności stosowania wykładni pozajęzykowej powinna być zatem wyznaczana przez precyzję ustawodawcy lub też świadomy jej brak, z uwagi na potrzebę osiągnięcia określonych celów $\mathrm{w}$ ramach polityki legislacyjnej i polityki podatkowej.

${ }^{16} \mathrm{Na}$ temat opodatkowania zbiorników wodnych retencyjnych zob. L. Etel, Podatek od nieruchomości, rolny, leśny, Warszawa 2005, s. 119 i n. 